\title{
Politik Hukum Pembentukan UU Paten di Indonesia: Industrialisasi, Liberalisasi, dan Harmonisasi
}

\author{
M. Zulfa Aulia \\ Fakultas Hukum Universitas Jambi \\ Jln. Raya Jambi Muara-Bulian KM. 15 Mendalo Darat Jambi \\ emzulfa@yahoo.com
}

\begin{abstract}
Patent protection in Indonesia still leaves various problems, both in terms of practical level (implementation) and conceptual level (public acceptance). This study aims to investigate the problematic patent protection from the point of governing law, in this case it is due to the reasons underlying its formation. This is a normative research with a political approach. The legal materials used in the form of the treatise of the trial establishment of patent law, Law No. 6 In 1989, Law No. 13 of 1997 and Law No. 14 of 2001 on Patents. Secondary legal materials in the form of articles that accompany or responded to the formation of the law, and the materials that explain the situation when the law was formed. It comes up with a conclusion that the establishment of the Patent Act is originally intended to encourage industrialization in the country, but in fact is more highly affected by the desire to keep abreast of political and international trade, especially that of developed countries, more adjusted to the substance of the Act by the International Agreement (TRIPs), and create better (foreign) investment climate. The assimilation of domestic-foreign interest more or less would affect the acceptance and implementation of patent protection leading to stumbling blocks as seen today.
\end{abstract}

Keywords: Patent law, legal politics, industrialization, and international treaties

\begin{abstract}
Abstrak
Perlindungan paten di Indonesia sejauh ini masih menyisakan beragam persoalan, baik yang sifatnya praktis (implementasi) maupun konseptual (penerimaan oleh masyarakat). Penelitian ini bertujuan untuk menyelidiki permasalahan perlindungan paten dari sudut UU yang mengaturnya, dalam hal ini berkenaan dengan alasan yang mendasari pembentukannya. Penelitian ini dikategorikan jenis penelitian normatif. Adapun bahan hukum yang dipergunakan berupa risalah persidangan pembentukan perundang-undangan paten, UU UU No. 6 Tahun 1989, UU No. 13 Tahun 1997, dan UU No. 14 Tahun 2001 tentang Paten. Bahan hukum sekunder berupa artikel-artikel yang mengiringi atau merespons pembentukan UU tersebut, dan bahan-bahan yang menjelaskan situasi ketika UU tersebut dibentuk. Hasil penelitian menyimpulkan bahwa pembentukan UU Paten yang pada mulanya dimaksudkan untuk mendorong industrialisasi di dalam negeri, dalam perkembangannya lebih disebabkan oleh kehendak untuk mengikuti perkembangan dan politik perdagangan internasional khususnya negara-negara maju, menyesuaikan materi muatan UU dengan Perjanjian Internasional (TRIPs), dan menciptakan iklim investasi (asing) yang lebih baik lagi. Adanya perbauran kepentingan domestik-asing tersebut sedikit atau banyak tentu berpengaruh terhadap penerimaan dan pelaksanaan perlindungan paten, sehingga mengalami hambatan, seperti yang dijumpai sekarang ini.
\end{abstract}

Kata kunci: UU Paten, politik hukum, industrialisasi, dan perjanjian internasional 


\section{Pendahuluan}

Perlindungan paten di Indonesia sejauh ini mengalami beragam persoalan, baik yang sifatnya praktis maupun konseptual. Secara praktis, permasalahan tersebut dapat dilihat dari sangat sedikitnya karya teknologi masyarakat Indonesia yang mendapatkan paten, dan karenanya berarti sebagian besar perlindungan paten ditujukan untuk karya teknologi yang berasal dari luar. Sejak 1992 sampai dengan 2010, teknologi masyarakat Indonesia yang mendapatkan perlindungan paten hanya 1.360 (setara 5,17\%), sedangkan sejumlah 24.922 (94,82\%) diberikan kepada inventor asing. ${ }^{1}$ Sekalipun terdaftar dan tidaknya suatu invensi seseorang sebagai paten dipengaruhi oleh banyak faktor, fakta demikian menunjukkan ada persoalan terkait dengan perlindungan paten di republik ini.

Permasalahan paten secara konseptual justru dirasa lebih mendasar, karena terkait dengan penerimaannya oleh masyarakat. Meski keberadaan UU Paten ${ }^{2}$ telah jelas-jelas menandakan bahwa sistem paten mengikat untuk berlaku bagi seluruh masyarakat Indonesia, suara masyarakat yang mengingkarinya masih banyak ditemui. Sebagai sistem hukum yang individualis, paten dinilai tidak tepat bagi masyarakat Indonesia yang sistem sosialnya cenderung lebih kolektif. ${ }^{3}$ Sistem paten yang "menganjurkan" monopoli atas hasil-hasil penemuan, dianggap justru hanya akan menjadi "sistem-sistem keserakahan". 4

Persoalan penerimaan paten tersebut diperparah dengan ketidakterjangkauan sistem paten dalam melindungi hak-hak dan karya-karya kolektif masyarakat. Padahal, banyak karya-karya di Indonesia yang selain tradisional juga dimiliki secara kolektif, seperti pengetahuan dan teknologi dalam pengobatan dan pemanfaatan sumber daya alam. Karya-karya tradisional dan kolektif tersebut tentu berkontribusi

${ }^{1}$ Http://mmw.dgip.go.id, diakses 20 Februari 2011. Dari 1.360 invensi domestik yang mendapatkan perlindungan paten tersebut, lebih separuhnya merupakan invensi paten sederhana, yaitu sejumlah 744 (54,7 persen). Ketika situs ini dikunjungi pada Maret 2015, peneliti tidak menemukan pemisahan antara paten yang diajukan oleh dan diberikan kepada inventor dalam negeri dan inventor asing.

${ }^{2}$ UU tentang Paten yang berlaku di Indonesia dimulai dari UU No. 6 Tahun 1989, yang kemudian diperbarui dengan UU 13 Tahun 1997, dan yang terbaru adalah UU No. 14 Tahun 2001.

${ }^{3}$ Dalam kaitan ini Edy Sedyawati mengatakan, kehidupan dengan kehangatan dan keikhlasan berbagi dalam karya cipta pada masyarakat tradisional sebaiknya tidak perlu diusik oleh isu hak cipta yang individual. Namun demikian, jangan sampai pula asas kebersamaan internal itu kemudian disalahgunakan oleh pihak-pihak di luar komuniti dan mengambil manfaat ekonomis darinya. Edy Sedyawati, "Masalah Berbagi dalam Ekspresi Budaya Tradisional," Media HKI, Direktorat Jenderal HKI, Departemen Hukum dan HAM RI, Jakarta, Vol. II/No. 2 April 2005, hlm. 11-13.

${ }^{4}$ RAFI (The Rural Advancement Foundation International), Enclosures of the Mind (Kapling-kapling Daya Cipta Manusia) (terj. A. Widyamartaya dan JD. Bowo Santosa), Cindelaras Pustaka Rakyat Cerdas, Yogyakarta, 2004, hlm. 19. 
besar bagi kehidupan umat manusia, seperti halnya karya-karya yang menjadi obyek perlindungan paten. ${ }^{5}$

Adanya persoalan-persoalan tersebut menimbulkan kecurigaan, karena apa dan untuk apa sebenarnya UU Paten itu dibuat. Penelitian ini dimaksudkan untuk menelaah bermasalahnya perlindungan Paten dari sudut UU yang mengaturnya. Hal ini didasari alasan bahwa UU itu pada dasarnya merupakan bagian dari hukum yang dibuat secara sengaja oleh badan negara yang berwenang, ${ }^{6}$ dan karenanya ia tidaklah muncul secara tiba-tiba, melainkan dibuat dengan alasan dan tujuan tertentu.

\section{Rumusan Masalah}

Permasalahan yang dikaji dalam penelitian ini adalah alasan apa yang melandasi pembentukan ketiga UU Paten yang pernah berlaku di Indonesia, yaitu UU No. 6 Tahun 1989, UU No. 13 Tahun 1997, dan UU No. 14 Tahun 2001 ?

\section{Tujuan Penelitian}

Penelitian ini bertujuan untuk menyelidiki bermasalahnya perlindungan paten dari sudut UU yang mengaturnya, dalam hal ini berkenaan dengan alasan yang mendasari pembentukan ketiga UU Paten yang pernah berlaku di Indonesia, yaitu UU No. 6 Tahun 1989, UU No. 13 Tahun 1997, dan UU No. 14 Tahun 2001.

\section{Metode Penelitian}

Studi tentang alasan yang melandasi pembentukan suatu UU pada dasarnya tergolong sebagai studi politik hukum. Sebagaimana dikemukakan Teuku Muhammad Radhie, politik hukum adalah pernyataan kehendak penguasa negara

5Dalam studi Agus Sardjono disebutkan, ketidakterjangkauan tersebut llebih disebabkan karena negaranegara maju (developed countries) yang memiliki pengaruh besar dalam pergaulan internasional, termasuk dalam kesepakatan di bidang HKI, enggan untuk memberikan pengakuan terhadap hak-hak kolektif masyarakat yang hidup (terutama) di negara berkembang (developing countries), disebabkan berkepentingan untuk tetap dapat mempertahankan (keuntungan) akses terhadapnya. Lihat Agus Sardjono, HKI dan Pengetabuan Tradisional,Alumni, Bandung, 2006, hlm. 356-358.

${ }^{6}$ Satjipto Rahardjo, Ilmu Hukum, cetakan keenam, Citra Aditya Bakti, Bandung, 2006, hlm. 83. 
mengenai hukum yang berlaku di wilayahnya.7 Berdasarkan definisi ini, maka hukum yang diberlakukan oleh pemerintah itu berarti memuat kehendak-kehendak tertentu dari pemerintah. Upaya menelaah "kehendak-kehendak tertentu" dari pemerintah itu antara lain dapat dilakukan dengan menyelidiki alasan yang mendasari terbentuknya suatu UU. Untuk itu, metode pendekatan dalam penelitian ini adalah pendekatan perundang-undangan.

Penelitian ini bertujuan untuk menyelidiki permasalahan perlindungan paten dari sudut UU yang mengaturnya, dalam hal ini berkenaan dengan alasan yang mendasari pembentukannya. Dengan demikian penelitian ini dikategorikan jenis penelitian normatif. Adapun bahan hukum yang dipergunakan berupa risalah persidangan pembentukan perundang-undangan paten, UU UU No. 6 Tahun 1989, UU No. 13 Tahun 1997, dan UU No. 14 Tahun 2001 tentang Paten. Bahan hukum sekunder berupa artikel-artikel yang mengiringi atau merespons pembentukan UU tersebut, dan bahan-bahan yang menjelaskan situasi ketika UU tersebut dibentuk.

\section{Hasil Penelitian dan Pembahasan}

\section{Perbauran Domestik-Nasional dan Asing-Negara Maju}

Sampai saat ini ada tiga UU Paten yang pernah dan salah satunya masih berlaku di Indonesia. Ketiga UU Paten tersebut adalah UU No. 6 Tahun 1989, UU No. 13 Tahun 1997, dan UU No. 14 Tahun 2001. UU Paten yang disebut terakhir merupakan UU Paten yang berlaku sekarang ini.

Sebagai UU Paten pertama, UU Paten Tahun 1989 mempunyai kedudukan yang sangat penting dalam suatu studi perlindungan paten di Indonesia. Sebab, melalui UU inilah perlindungan paten di Indonesia baru dimulai, sekalipun pada tahun-tahun sebelumnya telah dimungkinkan adanya pencatatan terhadap penemuan-penemuan yang hendak didaftarkan. Hal ini berarti perlindungan paten yang sebelumnya tidak ada kemudian diadakan oleh pemerintah melalui UU Paten 1989.

Secara historis, pembentukan UU Paten 1989 dimulai dengan keluarnya dua Pengumuman Menteri Kehakiman, yaitu Pengumuman Nomor J.S. 5/4I/4 pada 12

${ }^{7}$ Demikian definisi politik hukum menurut Teuku Muhammad Radhie, sebagaimana dikutip Imam Syaukani dan A. Ahsin Thohari, Dasar-dasar Politik Hukum, cetakan keempat, PT. RajaGrafindo Persada, Jakarta, 2007, hlm. 27. 
Agustus 1953 dan Pengumuman Nomor J.G. 1/2/17 pada 29 Oktober 1953. Pengumuman pertama berisi tentang dapat diajukannya permintaan paten oleh para inventor, meski sifatnya baru berupa pendaftaran sementara; 8 sedangkan pengumuman yang kedua berisi tentang pendaftaran paten sementara oleh inventor dari luar negeri. Melalui pengumuman yang pertama juga dinyatakan bahwa: "Menteri Kehakiman mengumumkan dengan ini, bahwa, mendahului akan adanya UU Oktroi, di Kementerian Kehakiman di Jakarta Selatan Jalan Segara 17, dapat diajukan permohonan sementara pendaftaran Oktroi mulai 1 November 1953".

Keluarnya pengumuman Menteri Kehakiman tersebut sesungguhnya adalah untuk mendahului atau mengawali pembentukan UU Oktroi, atau yang sekarang disebut UU Paten. Keinginan pemerintah untuk membentuk UU Paten nasional tersebut baru menunjukkan hasilnya di 1982, yaitu dengan disiapkannya RUU Paten, yang oleh Menteri Kehakiman diajukan kepada Presiden. Hanya saja RUU Paten ini pada 1986 dilakukan pengkajian ulang. Melalui Keputusan Presiden No. 34 Tahun 1986, Presiden membentuk sebuah tim yang (kemudian dikenali dengan Tim Keppres No. 34 Tahun 1986) ditugaskan untuk menyelesaikan penyusunan perundangundangan mengenai Hak Paten (dan juga Hak Cipta dan Merek). ${ }^{9}$ Dari RUU yang disiapkan tim inilah UU Paten kemudian terbentuk pada 1989.

Berkaitan dengan alasan dibentuknya UU Paten 1989, disebutkan dalam bagian konsideran: a. bahwa Negara Republik Indonesia adalah negara hukum berdasarkan Pancasila dan Undang-Undang Dasar 1945, bertujuan mewujudkan masyarakat yang adil dan makmur yang merata materiil dan spiritual; b. bahwa dalam rangka pelaksanaan pembangunan nasional pada umumnya dan pembangunan sektor ekonomi pada khususnya, teknologi memiliki peranan yang sangat penting artinya dalam usaha peningkatan dan pengembangan industri; c. bahwa dengan memperhatikan pentingnya peranan teknologi dalam peningkatan dan pengembangan industri tersebut, diperlukan upaya untuk mewujudkan iklim yang lebih baik bagi kegiatan penemuan teknologi dan perangkat untuk memberikan perlindungan hukum terhadap hasil kegiatan tersebut; d. bahwa untuk mewujudkan

${ }^{8}$ Permintaan paten yang diajukan inventor pada saat itu disebut pendaftaran sementara karena jawaban diterima atau tidaknya permintaan tersebut baru dapat diberikan setelah UU Paten, yang ketika itu disebut UU Oktroi, dibentuk nantinya.

${ }^{9}$ Keterangan Pemerintah di Hadapan Sidang Paripurna DPR RI Mengenai RUU Paten, yang diwakili oleh Menteri Kehakiman, Ismail Saleh, pada tanggal 16 Juni 1989. 
iklim dan perangkat perlindungan hukum sebagaimana tersebut diatas, dipandang perlu untuk segera menetapkan pengaturan mengenai paten dalam suatu undangundang.

Dari konsideran tersebut, yang juga diperjelas pada bagian penjelasan umum, tersimak bahwa UU Paten 1989 dimaksudkan sebagai perangkat perlindungan hukum bagi kegiatan penemuan teknologi. Perlindungan tersebut diperlukan karena teknologi dipandang memiliki peranan yang sangat penting bagi upaya peningkatan dan pengembangan industri. Dengan demikian, tampak bahwa alasan yang mendasari pembentukan UU Paten 1989 adalah kehendak pemerintah untuk meningkatkan dan mengembangkan industri.

Kalau tadi dikatakan bahwa UU Paten dibentuk untuk melindungi kegiatan penemuan teknologi yang diperlukan bagi peningkatan dan pengembangan industri, maka pertanyaannya: apa sebenarnya teknologi itu sehingga demikian diperlukan dalam pengembangan industri, dan mengapa sektor industri diharapkan semakin berkembang?

Teknologi adalah pengetahuan tentang pemakaian alat-alat dalam proses pembuatan barang-barang, ${ }^{10}$ atau juga teknik-atau suatu daya-upaya sistematisyang menggunakan penemuan-penemuan ilmiah. ${ }^{11}$ Ini berarti teknologi itu terkait dengan teknik dan penemuan-penemuan ilmiah. Pada mulanya antara teknik dan penemuan ilmiah itu tidaklah terjadi hubungan. Akan tetapi bila tidak terjadi hubungan di antara keduanya, maka penemuan-penemuan ilmiah tidak akan mempunyai nilai-nilai praktis. Adalah pendekatan industrial yang kemudian saling mendekatkan teknik dengan penemuan ilmiah, sehingga lambat-laun nilai-nilai praktis amat memengaruhi kegiatan ilmiah. Inilah sebabnya kenapa teknologi terkadang juga didefinisikan sebagai penggunaan industrial dari ilmu (industrial application of science). ${ }^{12}$

Mengapa pemerintah berhasrat mengembangkan industri, yang menurut keterangan Menteri Kehakiman pada waktu itu diharapkan dapat mengimbangi

${ }^{10}$ Amir Pamuntjak, "Dasar Pokok Alih Teknologi”, dalam Amir Pamuntjak, dkk., Sistem Paten: Pedoman Praktik dan Alih Teknologi, Djambatan, Jakarta, 1994, hlm. 7.

${ }^{11}$ Wiratmo Sukito, "Kaum Intelektual dan Teknokrat: Mencari Definisi”, Pengantar dalam Cendekiawan dan Politik, LP3ES, Jakarta, cetakan kedua, 1984, hlm. xvii. Lihat juga J.K. Galbraith, “Tuntutan-tuntutan Teknologi”, dalam Y.B. Mangunwijaya, Teknologi dan Dampak Kebudayaannya, Yayasan Obor Indonesia, Jakarta, cetakan ketiga, 1997, hlm. 13-23.

12Wiratmo Sukito, Loc. Cit. 
perkembangan sektor pertanian ${ }^{13}$ Di dalam UU Perindustrian disebutkan bahwa pembangunan industri diasumsikan dapat memperluas dan memeratakan kesempatan kerja dan kesempatan berusaha, mengurangi ketergantungan kepada luar negeri, memperbaiki mutu hasil produksi nasional yang pada gilirannya akan meningkatkan ekspor dan penerimaan devisa, terciptanya struktur ekonomi yang lebih baik dan maju, meningkatkan pertumbuhan ekonomi, dan pada akhirnya akan dapat meningkatkan kemakmuran dan kesejahteraan rakyat secara adil dan merata. ${ }^{14}$

Asumsi-asumsi seperti itulah yang tampaknya digunakan pemerintah untuk mengembangkan industri di Indonesia, dalam hal ini melalui perlindungan terhadap teknologi baru yang ditemukan. Apabila asumsi-asumsi tersebut dikaitkan dengan pembangunan suatu negara untuk menjadi maju, maka pendekatan industrial memang diyakini menjadi salah satu syaratnya. Sebagaimana ditulis Erman Rajagukguk, industrialisasi merupakan tahapan pembangunan kedua yang biasa dilakukan oleh suatu negara setelah yang pertama berupa terwujudnya persatuan nasional (unification) dan sebelum yang ketiga tercapainya kesejahteraan sosial (social welfare). ${ }^{15}$

Kalau memang UU Paten dibentuk untuk mengembangkan industri nasional, yang di dalamnya teknologi merupakan bagian terpentingnya, lalu benarkah UU Paten dapat mewujudkan iklim yang lebih baik bagi penemuan teknologi? Oleh karena UU Paten memberikan perlindungan bagi seseorang yang menemukan teknologi baru berupa hak untuk menggunakannya dan melarang penyalahgunaannya oleh pihak lain, maka adanya UU Paten sudah barang tentu dapat memberikan iklim yang lebih baik bagi kegiatan penemuan teknologi. Dengan jaminan perlindungan dalam penggunaan temuan-temuannya, setidaknya dari rumusan normatifnya, maka penemu (inventor) jelas akan lebih tenang dan nyaman dalam menggunakan temuantemuannya dan juga menghasilkan penemuan-penemuan berikutnya yang lebih baru

\footnotetext{
${ }^{13}$ Keterangan Pemerintah di Hadapan Sidang Paripurna DPR RI Mengenai RUU Paten, yang diwakili oleh Menteri Kehakiman, Ismail Saleh, pada tanggal 16 Juni 1989.

${ }^{14}$ Pasal 3.

${ }^{15}$ Ketiganya merupakan tahapan-tahapan pembangunan yang dikemukakan oleh ahli-ahli ilmu sosial di Barat dalam melihat perkembangan pembangunan yang berlangsung di negaranya. Bila dibandingkan dengan Negara Maju, masalah utama yang diahdapi Negara Berkembang sebenarnya ada dalam tahapan pembangunan ini, disebabkan Negara Maju menghadapi tahapan-tahapan itu satu demi satu, sementara Negara Berkembang harus menghadapinya dalam satu masa sekaligus. Lihat: Erman Rajagukguk, "Hukum Ekonomi Indonesia: Memperkuat Persatuan Nasional, Mendorong Pertumbuhan Ekonomi dan Memperluas Kesejahteraan Sosial”, makalah Seminar dan Lokakarya Pembangunan Hukum Nasional Ke-VIII, diselenggarakan oleh Badan Pembinaan Hukum Nasional, Departemen Kehakiman dan HAM RI, di Denpasar, 14-18 Juli 2003.
} 
lagi. Tujuan semacam ini sejalan dengan teori penghargaan (reward theory) dalam perlindungan paten, bahwa seseorang yang menghasilkan suatu penemuan, karena telah mengorbankan tenaga, biaya, waktu dan tentunya juga pikiran, maka kepadanya diberikan suatu penghargaan berupa hak untuk menggunakan penemuannya itu. ${ }^{16}$ Adanya penghargaan berupa hak penggunaan ini, diasumsikan akan turut memacu munculnya penemuan-penemuan berikutnya.

Dalam perkembangannya, UU Paten Tahun 1989 diperbarui dengan UU No. 13 Tahun 1997.Pembaruan UU Paten ini antara lain tergambar pada bagian konsideran, yaitu: a. bahwa dengan adanya perkembangan kehidupan yang berlangsung cepat, terutama di bidang perekonomian baik di tingkat nasional maupun internasional pemberian perlindungan hukum yang semakin efektif terhadap Hak Atas Kekayaan Intelektual, khususnya di bidang Paten, perlu lebih ditingkatkan dalam rangka mewujudkan iklim yang lebih baik bagi tumbuh dan berkembangnya kegiatan penelitian yang menghasilkan penemuan dan pengembangan teknologi yang sangat diperlukan dalam pelaksanaan pembangunan nasional yang bertujuan terciptanya masyarakat Indonesia yang adil, makmur, maju, dan mandiri berdasarkan Pancasila dan UndangUndang Dasar 1945; b. bahwa dengan penerimaan dan keikutsertaan Indonesia dalam Persetujuan tentang Aspek-aspek Dagang Hak Atas Kekayaan Intelektual (Agreement on Trade Related Aspects of Intellectual Property Rights, Including Trade in Counterfeit Goods/TRIPs) yang merupakan bagian dari Persetujuan Pembentukan Organisasi Perdagangan Dunia (Agreement Establishing the World Trade Organization) sebagaimana telah disahkan dengan Undang-undang, berlanjut dengan melaksanakan kewajiban untuk menyesuaikan peraturan perundang-undangan nasional di bidang Hak Atas Kekayaan Intelektual termasuk Paten dengan persetujuan internasional tersebut; c. bahwa berdasarkan pertimbangan sebagaimana tersebut dalam huruf $a$ dan $b$ serta memperhatikan penilaian terhadap segala pengalaman, khususnya kekurangan selama pelaksanaan UU tentang Paten, dipandang perlu untuk mengubah dan menyempurnakan beberapa ketentuan UU No. 6 Tahun 1989 tentang Paten dengan UU.

Berdasarkan konsideran tersebut, terlihat bahwa perubahan terhadap UU Paten Tahun 1989 dimaksudkan untuk menyesuaikan UU Paten dengan ketentuan TRIPs, membenahi dan menyempurnakan kekurangan pada UU Paten 1989, menjawab

${ }^{16}$ Lihat: Robert M. Sherwood, Intellectual Property and Economic Development,Alexandria, Virginia, 1990, hlm. 37;Bambang Kesowo, "UU Paten: Latar Belakang dan Prinsip-Prinsip Pokok",dalam Paten, Pemahaman dan Pelaksanaan,Pusat Pengkajian Hukum, tanpa kota, 1993, hlm. 31. 
perkembangan ekonomi yang sangat cepat, menciptakan iklim kegiatan penemuan dan pengembangan teknologi yang lebih baik lagi, dan melaksanakan pembangunan nasional. Di antara alasan-alasan tersebut, alasan menyesuaikan UU Paten dengan ketentuan di dalam TRIPs tampaknya menjadi alasan utama, sedangkan yang lainnya lebih merupakan keterangan penjelas saja layaknya suatu "lipstik" yang ditujukan untuk memperindah bangunan UU.

Mengapa alasan penyesuaian UU Paten dengan TRIPs dikatakan sebagai alasan utamanya? Sebabnya ialah, hampir seluruh materi pokok yang diperbaharui berdasarkan UU Paten yang baru (1997) ini memang dimaksudkan untuk menyesuaikan isi UU Paten dengan TRIPs. Di antaranya adalah materi tentang jangka waktu perlindungan,17 hak eksklusif yang meliputi pula hak mengimpor, ${ }^{18}$ penghapusan ketentuan yang menyatakan penemuan makanan, minuman serta varietas baru tanaman dan hewan sebagai penemuan yang tidak dapat dipatenkan,, ${ }^{19}$ dan juga pembebanan pembuktian terbalik bagi pelanggarnya. ${ }^{20}$

Dari sudut perkembangan perekonomian internasional, perubahan UU Paten yang lebih dimaksudkan untuk menyesuaikannya dengan perjanjian internasional tersebut merupakan bagian dari upaya liberalisasi ekonomi di tingkatan internasional. Agar liberalisasi atau internasionalisasi ekonomi ini berjalan dengan baik, maka

${ }^{17}$ Berdasarkan UU yang lama (Pasal 9 dan 10), jangka waktu perlindungan paten adalah 14 tahun, dan untuk paten sederhana 5 tahun. Di dalam UU yang baru (Ketentuan Angka 4 dari Pasal 1), jangka waktu tersebut diubah menjadi 20 tahun untuk paten (biasa) dan 10 tahun untuk paten sederhana. Perubahan jangka waktu perlindungan dari 14 tahun menjadi 20 tahun merupakan penyesuaian UU Paten terhadap Pasal 33 TRIPs, yaitu: "the term of protection available shall not end before the expiration of a period of twenty years counted from the filing date".

${ }^{18}$ Di dalam UU yang lama (Pasal 17), hak paten meliputi kegiatan membuat, menggunakan (dalam hal paten yang diberikan berupa proses), menjual, menyewakan, menyerahkan, memakai, dan menyediakannya untuk dijual, disewakan, atau diserahkan, suatu penemuan. Berdasarkan UU yang baru (Ketentuan Angka 8 dari Pasal 1), yang termasuk sebagai hak paten, selain hak-hak menurut UU lama, juga mencakup kegiatan mengimpor. Perubahan cakupan hak ini merupakan penyesuaian UU Paten terhadap Pasal 28 Ayat (1) TRIPs, "a patent shall confer on its owner the following exclusive rights: (a) where the subject matter of a patent is a product, to prevent third parties not having the owner's consent from the acts of: making, using, offering for sale, selling, or importing for these purposes that product; (b) where the subject matter of a patent is a process, to prevent third parties not having the owner's consent from the act of using the process, and from the acts of: using, offering for sale, selling, or importing for these purposes at least the product obtained directly by that process.

${ }^{19}$ UU yang lama (Pasal 7) menggolongkan penemuan berupa makanan, minuman serta varietas baru tanaman dan hewan sebagai penemuan yang tidak dapat dipatenkan. Pengecualian ini di dalam UU yang baru (Ketentuan Angka 5 dari Pasal 1) dihapuskan, sehingga termasuk sebagai penemuan yang dapat dipatenkan. Perubahan ini merupakan penyesuaian UU Paten terhadap Pasal 27 Ayat (3) TRIPs, yaitu: “... members shall provide for the protection of plant varieties either by patents or by an effective sui generis system or by any combination thereof...".

${ }^{20}$ Ketentuan Angka 45 Pasal 1. Materi ini merupakan penyesuaian UU Paten terhadap Pasal 34 TRIPs, yaitu: "for the purposes of civil proceedings in respect of the infringement of the rights of the owner referred to in paragraph 1(b) of Article 28, if the subject matter of a patent is a process for obtaining a product, the judicial authorities shall have the authority to order the defendant to prove that the process to obtain an identical product is different from the patented process". 
dengan sendirinya menuntut perubahan pranata-pranata sosial-politik dan hukum. ${ }^{21}$ Hal inilah yang menyebabkan kenapa penyesuaian pada pranata hukum (termasuk dalam bentuk pembaruan UU) dalam bidang paten (dan juga bidang hak kekayaan intelektual lainnya) dilakukan.

Setelah berlaku selama empat tahun, UU Paten 1997 diganti dengan UU No. 14 Tahun 2001. Di dalam konsideran UU Paten yang baru disebutkan: a. bahwa sejalan dengan ratifikasi Indonesia pada perjanjian-perjanjian internasional, perkembangan teknologi, industri, dan perdagangan yang semakin pesat, diperlukan adanya UU Paten yang dapat memberikan perlindungan yang wajar bagi Inventor; b. bahwa hal tersebut pada butir a juga diperlukan dalam rangka menciptakan iklim persaingan usaha yang jujur serta memperhatikan kepentingan masyarakat pada umumnya; c. bahwa berdasarkan pertimbangan sebagaimana tersebut dalam huruf a dan b serta memperhatikan pengalaman dalam melaksanakan UU Paten yang ada, dipandang perlu untuk menetapkan UU Paten yang baru menggantikan UU No. 6 Tahun 1989 tentang Paten sebagaimana telah diubah dengan UU No. 13 Tahun 1997 tentang Perubahan atas UU No. 6 Tahun 1989 tentang Paten.

Dalam konsideran terlihat bahwa latar belakang yang mendasari pembentukan UU Paten Tahun 2001 adalah ratifikasi perjanjian-perjanjian internasional serta perkembangan teknologi, industri, dan perdagangan yang pesat. Berangkat dari dua kondisi inilah UU Paten yang baru disusun, dengan harapan dapat memberikan perlindungan kepada inventor dan sekaligus menciptakan iklim persaingan usaha yang jujur.

Berkaitan dengan perjanjian internasional yang diratifikasi, yang dimaksud dengannya adalah TRIPs. Perjanjian ini juga menjadi dasar dalam pembentukan UU Paten sebelumnya (UU Tahun 1997). Karena dipandang ada materi muatan dalam UU lama yang belum disesuaikan dengan materi muatan TRIPs, maka UU baru dibentuk untuk lebih menyesuaikannya lagi. ${ }^{22}$

Apabila alasan untuk menyesuaikan ketentuan TRIPs tersebut dikaji dari materi muatan UU yang dibentuk, maka tidaklah banyak sebenarnya penyesuaian yang dilakukan. Penyesuaian terhadap TRIPs hanya meliputi penggolongan invensi

${ }^{21}$ Todung Mulya Lubis, "Reformasi Hukum Ekonomi: Harmonisasi dan Internasionalisasi”, dalam Seri Debat Publik Seputar Reformasi: Opini Masyarakat dari Krisis ke Reformasi, Demokratisasi dan Otonomi,Kompas, Jakarta, 1999, hlm. 19-26.

22 Lihat paragrap ketiga Penjelasan Umum UU Paten Tahun 2001. 
varietas tanaman sebagai invensi yang tidak dapat dipatenkan ${ }^{23}$ dan juga pengecualian impor produk farmasi dari pelanggaran paten. ${ }^{24}$ Varietas tanaman dikelompokkan sebagai invensi yang tidak dapat dipatenkan karena sudah dibuatkan UU tersendiri, yaitu UU No. 29 Tahun 2000. Hal ini sejalan dengan ketentuan TRIPs yang memungkinkan negara anggota untuk memilih memberikan perlindungan varietas tanaman melalui paten atau sistem sui generis. ${ }^{25}$ Begitu juga dengan pengecualian impor produk farmasi dari pelanggaran paten, hal ini juga dimungkinkan oleh TRIPs. ${ }^{26}$

Di luar alasan yang tersebut dalam konsideran dan bagian penjelasan, tersua pula alasan pembentukan UU Paten Tahun 2001 dalam pemandangan umum dan pendapat akhir fraksi-fraksi DPR yang mengemuka pada saat pembahasan. Dari pemandangan umum dan pendapat akhir fraksi-fraksi, diketahui bahwa pembentukan UU Paten juga terkait dengan politik dagang Negara Maju,perdagangan bebas, iklim investasi asing, dan penggunaan UU Paten oleh masyarakat. ${ }^{27}$

Dari berbagai alasan tersebut, alasan yang berkaitan dengan politik perdagangan Negara Maju menarik untuk dicermati. Adanya politik dagang dari Negara Maju terutama AS agar produk-produk HKI mereka dilindungi, memang telah menjadi kenyataan yang tidak terelakkan lagi dalam perkembangan perdagangan internasional mutakhir. Seperti disebutkan Fraksi Kebangkitan Bangsa ketika menyampaikan pemandangan umum terhadap RUU, Amerika Serikat (AS) menuduh negara-negara mitra dagangnya seperti di Asia telah banyak merugikan produkproduk HKI mereka akibat tidak baiknya perlindungan HKI.

Apa yang mengemuka dalam pembahasan RUU tersebut, sejalan dengan perkembangan politik perdagangan AS yang terjadi pada 2001, di mana AS memulai mengumumkan penilaiannya terhadap perlindungan HKI di negara-negara mitra dagangnya. Penilaian tersebut dikelompokkan ke dalam tiga kategori, yaitu priority foerign country, priority watch list, dan watch list. Negara yang berada pada kategori pertama, yang merupakan kategori untuk negara dengan pelang-garan HKI yang sangat tinggi, berpeluang mendapatkan sanksi dagang dari AS, sementara pada

23 Pasal 7 UU Paten 2001.

24 Pasal 135 UU Paten 2001.

${ }^{25}$ Menurut Pasal 27 Ayat (3)b TRIPs: “...members shall provide for the protection of plant varieties either by patents or by an effective sui generis system or by any combination thereof...".

${ }^{26}$ Pasal 8 TRIPs: "members may, in formulating or amending their laws and regulations, adopt measures necessary to protect public health and nutrition, and to promote the public interest in sectors of vital importance to their socio-economic and technological development, provided that such measures are consistent with the provisions of this Agreement".

${ }^{27}$ Lihat Risalah Persidangan dalam penyusunan UU Paten 2001. 
kategori yang kedua dan ketiga akan mendapatkan pengawasan. ${ }^{28}$ Meski penilaian tersebut diberikan oleh Kantor Dagang AS (United State Trade Representative, USTR), keputusan mengenai hasil evaluasi tersebut sebenarnya ditentukan oleh rekomendasi yang diberikan International Intellectual Property Alliance (IIPA), yang merupakan gabungan dari enam asosiasi yang mewakili industri AS berkaitan dengan HKI. ${ }^{29}$ Pembentukan UU Paten 2001 tidak bisa dilepaskan dari faktor dorongan politik perdagangan semacam itu. Dibentuknya UU Paten yang baru yang lebih sesuai dengan politik perdagangan Negara Maju, akan dianggap sebagai keseriusan pemerintah dalam membenahi perlindungan HKI di Indonesia.

Alasan lainnya yang juga perlu dicermati terkait pembentukan UU Paten yang baru, ialah alasan menciptakan iklim yang lebih baik bagi penarikan investasi asing. Alasan ini bermula dari anggapan bahwa adanya jaminan perlindungan terhadap teknologi yang dibawa ke dalam negeri akan menjadikan investor merasa aman dengan investasi yang dikembangkannya. Dalam kaitan ini, Indonesia harus membentuk sistem paten dan berupaya memberikan perlindungan hukumnya dengan sebaik-baiknya, karena ia merupakan bagian dari iklim investasi yang dikehendaki oleh pihak asing. ${ }^{30}$

Berkaitan dengan alasan pembentukan UU yang ditujukan untuk memudahkan penggunaan UU Paten oleh masyarakat, maka hal ini mudah dimengerti. Sebab, UU Paten 1997 ternyata hanya memuat materi perubahan saja, sedangkan materi yang tidak diubah tidak dicantumkan. Model penyusunan UU yang demikian tentu saja merepotkan dalam penggunaannya, karena untuk melihat materi muatan UU tentang Paten secara utuh, pembaca harus pula membuka UU yang lama.

Sampai batas uraian di sini, tampak bahwa alasan pembentukan UU Paten di Indonesia sesuai periode keberlakuannya telah mengalami pergeseran. Jika pada mulanya UU Paten dibentuk untuk mendorong peningkatan dan perkembangan industri di dalam negeri, di mana iklim penemuan dan pengembangan teknologi yang baik merupakan salah satu syaratnya; maka dalam perkembangannya hal-hal yang

${ }^{28}$ Bisnis Indonesia, (10 Januari 2007), "Penegakan HaKI di 2007 Masih Penuh Tantangan".

${ }^{29}$ Bisnis Indonesia, (21 Februari 2007), "Mencermati Rekomendasi IIPA Soal HaKI".

${ }^{30}$ Investasi asing di Negara Berkembang diperlukan untuk memaksimalkan pemanfaatan sumber daya alam yang tersedia.Namun demikian, seharusnyalah langkah menarik investasi asing ini dijadikan sebagai langkah taktis saja, dan sebagai langkah strategisnya perlu dikembangkan SDM sendiri, salah satunya dilakukan dengan memanfaatkan investasi asing tersebut.Lihat A. Zen Umar Purba, Hak Kekayaan Intelektual Pasca TRIPs, Alumni, Bandung, 2005, hlm. 84-96. 
lebih memengaruhi adalah kehendak untuk mengikuti perkembangan dan politik perdagangan internasional (baca: negara-negara maju), menyesuaikan materi muatan UU dengan TRIPs, dan menciptakan iklim investasi (asing) yang lebih baik lagi. Industrialisasi di dalam negeri, liberalisasi perdagangan, dan harmonisasi perundangundangan, dengan demikian menjadi kata kunci dalam pembentukan UU Paten di Indonesia.

Berdasarkan ragam alasan pembentukan UU yang demikian itu, maka mudah dimengerti mengapa perlindungan paten di Indonesia masih menyisakan beragam masalah. Pembentukan UU Paten ternyata tidak sepenuhnya karena alasan domestik dan nasional (mengembangkan industri di dalam negeri), tetapi telah berkelindan dengan kepentingan-kepentingan asing (menyesuaikan materi UU dengan TRIPs, mengikuti politik dagang negara maju, dan memperbaiki iklim investasi asing). Perbauran kepentingan domestik-nasional dan asing-negara maju tersebut sedikit atau banyak jelas berpengaruh terhadap keberlakuan UU yang dibentuk, terlebih jika materi muatannya juga dirasa asing oleh masyarakat pribumi.

Fakta yang demikian ini mengonfirmasi dampak negatif yang diakibatkan dari globalisasi, di mana negara-terutama negara berkembang-tidak bebas lagi dalam membentuk hukum dan kebijakan nasionalnya dengan semata-matauntuk kepentingan domestiknya. Keterkaitan suatu negara dengan dunia internasional, baik melalui organisasi-organisasi internasional, perusahaan multinasional, sistem negosiasi inter-organisasi dan proses standarisasi global, asosiasi global, dana global, dan LSM internasional, menyebabkan negara semakin tergerus kedaulatan dan otonominya dalam membentuk hukum dan kebijakan nasionalnya. ${ }^{31}$

\section{Penutup}

Berdasarkan studi politik hukum, permasalahan dalam perlindungan paten di Indonesia sejauh ini, baik yang sifatnya praktis maupun konseptual, dipahami sebagai permasalahan yang berkait erat dengan alasan yang mendasari pembentukan UU Paten. Dalam studi ini ditunjukkan, pembentukan UU Paten yang semula lebih didasari semangat kepentingan domestik-nasional, dalam perkembangannya

\footnotetext{
${ }^{31}$ Lihat: Dian Rositawati, "Kedaulatan Negara dalam Pembentukan Hukum di Era Globalisasi”, dalam Sulistyowati Irianto (editor), Hukum yang Bergerak: Tinjanan Antropologi Hukum, Yayasan Obor Indonesia, Jakarta, 2009, hlm. 43-59.
} 
berkelindan dengan kepentingan asing-negara maju. Jika semula UU Paten dibentuk untuk mendorong berkembangnya industri di dalam negeri, dalam perkembangannya pembentukan UU Paten lebih disebabkan oleh kehendak untuk mengikuti perkembangan dan politik perdagangan internasional, menyesuaikan UU dengan perjanjian internasional (TRIPs), dan memperbaiki iklim investasi (asing). Industrialisasi (pengembangan industri), liberalisasi (integrasi pada perdagangan internasional khususnya perdagangan negara maju), dan harmonisasi (penyesuaian dan penyelerasan materi muatan UU dengan TRIPs), dengan demikian menjadi kata kunci dalam pembentukan UU Paten di Indonesia.

Adanya perbauran kepentingan domestik-asing tersebut sedikit atau banyak tentu berpengaruh terhadap penerimaan dan pelaksanaan perlindungan paten sehingga mengalami hambatan-hambatan, seperti dikemukakan pada awal tulisan. Meskipun perbauran kepentingan domestik-asing sebenarnya menjadi suatu keniscayaan dalam perkembangan pergaulan internasional sekarang ini, ia menjadi tidak wajar dan sulit diterima manakala kepentingan asing justru lebih mendominasi dan menentukan ketimbang kepentingan domestik-nasional.

\section{Daftar Pustaka}

Alun, Tawang, "Pengembangan Teknologi Sebagai Salah Satu Perangkat Kebijaksanaan Pembangunan Nasional", Prisma, No. 4 Tahun XVI April 1987.

Bisnis Indonesia, (10 Januari 2007), "Penegakan HaKI di 2007 Masih Penuh Tantangan”.

Bisnis Indonesia, (21 Februari 2007), "Mencermati Rekomendasi IIPA Soal HaKI".

Galbraith, J.K., "Tuntutan-tuntutan Teknologi”, dalam Y.B. Mangunwijaya, Teknologi dan Dampak Kebudayaannya,Yayasan Obor Indonesia, Jakarta, cetakan ketiga, 1997.

Kesowo, Bambang, “UU Paten: Latar Belakang dan Prinsip-Prinsip Pokok",dalam Paten, Pemahaman dan Pelaksanaan, Pusat Pengkajian Hukum, tanpa kota, 1993.

M. Sherwood, Robert, Intellectual Property and Economic Development, Alexandria, Virginia, 1990.

Mulya Lubis, Todung, "Reformasi Hukum Ekonomi: Harmonisasi dan Internasionalisasi", dalam Seri Debat Publik Seputar Reformasi: Opini Masyarakat dari Krisis ke Reformasi, Demokratisasi dan Otonomi, Kompas, Jakarta, 1999.

Pamuntjak, Amir, "Dasar Pokok Alih Teknologi", dalam Amir Pamuntjak, dkk., Sistem Paten: Pedoman Praktik dan Alih Teknologi, Djambatan, Jakarta, 1994. 
RAFI (The Rural Advancement Foundation International), Enclosures of the Mind (Kapling-kapling Daya Cipta Manusia) (terj. A. Widyamartaya dan JD. Bowo Santosa), Cindelaras Pustaka Rakyat Cerdas, Yogyakarta, 2004.

Rajagukguk, Erman, “Hukum Ekonomi Indonesia: Memperkuat Persatuan Nasional, Mendorong Pertumbuhan Ekonomi dan Memperluas Kesejahteraan Sosial", makalah Seminar dan Lokakarya Pembangunan Hukum Nasional Ke-VIII, diselenggarakan oleh Badan Pembinaan Hukum Nasional, Departemen Kehakiman dan HAM RI, di Denpasar, 14-18 Juli 2003.

Rositawati, Dian, "Kedaulatan Negara dalam Pembentukan Hukum di Era Globalisasi", dalam Sulistyowati Irianto (editor), Hukum yang Bergerak: Tinjauan Antropologi Hukum,Yayasan Obor Indonesia, Jakarta: 2009.

Rahardjo, Satjipto, Ilmu Hukum, Citra Aditya Bakti, Bandung, cetakan keenam, 2006.

Sardjono, Agus, HKI dan Pengetahuan Tradisional, Alumni, Bandung, 2006.

Sedyawati, Edy, "Masalah Berbagi dalam Ekspresi Budaya Tradisional," Media HKI, Direktorat Jenderal HKI, Departemen Hukum dan HAM RI, Jakarta, Vol. II/No. 2 April 2005.

Soepomo, Hubungan Individu dan Masyarakat dalam Hukum Adat,Pradnya Paramita, Jakarta, cetakan ketiga, 1978.

Soekanto, Soerjono, Fungsi Hukum dan Perubahan Sosial, Citra Aditya Bakti, Bandung, cetakan ketiga, 1991.

Sukito, Wiratmo, "Kaum Intelektual dan Teknokrat: Mencari Definisi", Pengantar dalam Cendekiawan dan Politik,LP3ES, Jakarta, cetakan kedua, 1984.

Syaukani, Imam dan A. Ahsin Thohari, Dasar-dasar Politik Hukum,RajaGrafindo Persada, Jakarta, cetakan keempat, 2007.

Waridin, "Pembangunan Pertanian dalam Mewujudkan Ketahanan Pangan dan Pengentasan Kemiskinan", Pidato Pengukuhan Guru Besar dalam Ilmu Ekonomi, FE Universitas Diponegoro,Semarang, 20 Desember 2008.

Zen Umar Purba, A., Hak Kekayaan Intelektual Pasca TRIPs, Alumni, Bandung, 2005.

Http://www.dgip.go.id, diakses 20 Februari 2011 dan 25 Maret 2015. 